\title{
Casein and soybean protein-based thermoplastics and composites as alternative biodegradable polymers for biomedical applications
}

\author{
C. M. Vaz, ${ }^{1}$ M. Fossen ${ }^{2}$ R. F. van Tuil, ${ }^{2}$ L. A. de Graaf, ${ }^{2}$ R. L. Reis, ${ }^{1}$ A. M. Cunha ${ }^{1}$ \\ ${ }^{1}$ Department of Polymer Engineering, University of Minho, Campus de Azurém, 4800-058 Guimarães, Portugal \\ ${ }^{2}$ ATO, Agrotechnological Research Institute, P. O. Box 17, NL-6700 AA Wageningen, The Netherlands
}

Received 2 February 2001; revised 26 March 2002; accepted 10 May 2002

\begin{abstract}
This work reports on the development and characterization of novel meltable polymers and composites based on casein and soybean proteins. The effects of inert $\left(\mathrm{Al}_{2} \mathrm{O}_{3}\right)$ and bioactive (tricalcium phosphate) ceramic reinforcements over the mechanical performance, water absorption, and bioactivity behavior of the injection-molded thermoplastics were examined. It was possible to obtain materials and composites with a range of mechanical properties, which might allow for their application in the biomedical field. The incorporation of tricalcium phosphate into the soybean thermoplastic decreased its mechanical properties but lead to the nucleation of a bioactive calciumphosphate film on their surface when immersed in a simulated body fluid solution. When compounded with $1 \%$ of a zirconate coupling agent, the nucleation and growth of the
\end{abstract}

bioactive films on the surface of the referred to composites was accelerated. The materials degradation was studied for ageing periods up to 60 days in an isotonic saline solution. Both water uptake and weight loss were monitored as a function of the immersion time. After 1 month of immersion, the materials showed signal of chemical degradation, presenting weight losses up to $30 \%$. However, further improvement on the mechanical performance and the enhancement of the hydrolytic stability of those materials will be highly necessary for applications in the biomedical field. (c) 2003 Wiley Periodicals, Inc. J Biomed Mater Res 65A: 60-70, 2003

Key words: soybean; casein; thermoplastic proteins; biomaterials; biodegradable polymers; degradation; bioactivity

\section{INTRODUCTION}

The concept of combining the biodegradability and high availability of natural polymers is attracting scientists from diverse areas. A good example is the proposal of blends of several starch based blends. ${ }^{1-3}$ as an alternative to the most common biodegradable polymers applied in the biomedical field, such as polylactic acid, ${ }^{4,5}$ polyhydroxybutyrate, ${ }^{4,6}$ and polyglycolic acid. ${ }^{4,5}$ However, the number of biopolymers in clinical use is rather small and stills presenting several weaknesses. ${ }^{7}$ A potential solution to overcome these difficulties may rely on the development of new materials, such as new protein-based thermoplastics (from vegetable or animal origin). Their high chemical

Correspondence to: C. M. Vaz; e-mail: claudiavaz@dep. uminho.pt

Contract grant sponsor: Portuguese Foundation for Science and Technology (FCT), Ministry of Science and Technology, Portugal; contract contract number: PRAXIS XXI PhD Grant (to C.M.V.)

(C) 2003 Wiley Periodicals, Inc. versatility $^{8-10}$ and similarity to tissue constituents ${ }^{11}$ may lead to the introduction of novel biomaterials into the clinical area. To our knowledge, until now only collagen and gelatine have been extensively studied and used. ${ }^{12-14}$ However, the introduction of other protein-based biomaterials may be of extreme importance if they could combine 1) the main advantages of collagen and gelatine; 2) reduced susceptibility to thermal degradation (allowing for its easy processing by melt based technologies into complex 3D implants); and 3) convenient degradation behavior. The good processability, both in aqueous media and in the melt, ${ }^{15,16}$ good film-forming properties, ${ }^{15,17}$ good adhesion to various substrates, ${ }^{18,19}$ and surface active properties $^{20}$ can differentiate positively proteins from other biopolymers. Furthermore, proteins are very versatile materials, both by source and because of a wide variety scale of possible modifications, so their properties can be tailored towards the diverse requirements of a specific application. As a result, proteins may be regarded as an eventual ideal template suitable for being used as biomaterials. Temporary replacement implants, tissue-engineering scaffolding, 
TABLE I

Mechanical Properties of the Developed Protein Materials and Their Respective Composites

\begin{tabular}{lcrrr}
\hline \multicolumn{1}{c}{ Material } & $E_{1 \%}(\mathrm{MPa})$ & \multicolumn{1}{c}{$\begin{array}{c}\text { UTS } \\
(\mathrm{MPa})\end{array}$} & $\begin{array}{c}\text { Moisture Content } \\
(\%)\end{array}$ \\
\hline $\mathrm{CAS}$ & $2534 \pm 60$ & $48.5 \pm 7.0$ & $2.2 \pm 0.5$ & $3.90 \pm 0.13$ \\
$\mathrm{CAS}+10 \mathrm{Al}_{2} \mathrm{O}_{3}$ & $2010 \pm 55$ & $39.2 \pm 0.5$ & $6.4 \pm 2.4$ & $3.74 \pm 0.02$ \\
$\mathrm{CAS}+30 \mathrm{Al}_{2} \mathrm{O}_{3}$ & $3479 \pm 59$ & $44.1 \pm 1.6$ & $2.4 \pm 0.6$ & $3.22 \pm 0.31$ \\
$\mathrm{SI}$ & $1256 \pm 101$ & $33.3 \pm 4.6$ & $16.5 \pm 6.9$ & $5.06 \pm 0.50$ \\
$\mathrm{SI}+10 \mathrm{Al}_{2} \mathrm{O}_{3}$ & $1699 \pm 83$ & $33.4 \pm 2.3$ & $2.8 \pm 0.5$ & $4.40 \pm 0.01$ \\
$\mathrm{SI}+30 \mathrm{Al}_{2} \mathrm{O}_{3}$ & $2481 \pm 136$ & $32.3 \pm 0.9$ & $3.1 \pm 0.2$ & $3.34 \pm 0.17$ \\
$\mathrm{SI}+10 \mathrm{TCP}$ & $680 \pm 20$ & $17.0 \pm 0.3$ & $23.2 \pm 5.8$ & $8.57 \pm 0.08$ \\
$\mathrm{SI}+30 \mathrm{TCP}$ & $896 \pm 58$ & $17.8 \pm 0.2$ & $12.1 \pm 1.6$ & $7.65 \pm 0.23$ \\
$\mathrm{SI}+\mathrm{NZ}$ & $299 \pm 20$ & $6.4 \pm 0.2$ & $23.7 \pm 0.6$ & $9.74 \pm 0.09$ \\
$\mathrm{SI}+10 \mathrm{Al}_{2} \mathrm{O}_{3}+\mathrm{NZ}$ & $425 \pm 28$ & $12.1 \pm 0.6$ & $23.1 \pm 1.7$ & $9.09 \pm 0.51$ \\
$\mathrm{SI}+30 \mathrm{Al}_{2} \mathrm{O}_{3}+\mathrm{NZ}$ & $382 \pm 25$ & $10.7 \pm 0.1$ & $26.4 \pm 2.7$ & $7.76 \pm 0.05$ \\
$\mathrm{SI}+10 \mathrm{TCP}+\mathrm{NZ}$ & $586 \pm 24$ & $15.0 \pm 0.2$ & $13.1 \pm 4.4$ & $8.96 \pm 0.37$ \\
$\mathrm{SI}+30 \mathrm{TCP}+\mathrm{NZ}$ & $601 \pm 31$ & $13.8 \pm 0.3$ & $7.87 \pm 0.07$ \\
\hline
\end{tabular}

membranes for promoting wound healing, and drug delivery carriers are the most promising target applications. In this preliminary work, new casein and soybean thermoplastic formulations were developed by extrusion compounding. The effects of inert (alumina, used as a model system) and bioactive (tricalcium phosphate, a bone-like ceramic) ceramic reinforcements over the composites mechanical properties, its degradation behavior, and bioactivity character were examined.

\section{MATERIALS AND METHODS}

\section{Materials}

Soybean protein isolate (SI) with a protein content of 90-91\% (dry basis) was provided by Protein Technology International. DMV International (The Netherlands) supplied the whole casein protein (CAS). Additionally, a food-grade plasticizer (glycerol) and a coupling agent (Neopentyl(diallyl)oxytri(dioctyl)phosphate zirconate, $\mathrm{NZ} 12, \mathrm{pH}=6$ ) were used as received from the manufacturers: Merck (The Netherlands) and Ken-React, (Kenrich Petrochemicals), respectively. The SI and CAS polymers were reinforced with an inert and a bioactive ceramic filler, namely 1 ) alumina $\left(\mathrm{Al}_{2} \mathrm{O}_{3}\right.$, Hüber, The Netherlands) and 2) tricalcium phosphate (TCP, $\mathrm{Ca}_{3}\left(\mathrm{PO}_{4}\right)_{2}$, Merck, The Netherlands), both with an average particle size smaller than $20 \mu \mathrm{m}$.

\section{Materials processing}

SI and CAS formulations with 0,10 , and $30 \%$ (wt $\%$ ) of $\mathrm{Al}_{2} \mathrm{O}_{3}$ (respectively, $\mathrm{SI}, \mathrm{SI}+10 \mathrm{Al}_{2} \mathrm{O}_{3}$ and $\mathrm{SI}+30 \mathrm{Al}_{2} \mathrm{O}_{3}$ ) were compounded in a corotating twin-screw extruder (Berstorff ZE $25(C L) \times 40 D)$ in the presence of $10 \%$ of glycerol and $30 \%$ of water (both wt \% of the protein weight). SI-based formu- lations also were mixed with 10 and $30 \%$ (wt \%) of TCP (respectively, SI, SI $+10 \mathrm{TCP}$, and SI $+30 \mathrm{TCP}$ ). For the preparation of the coupled composites, the above formulations were also mixed, during the extrusion procedure, with $1 \%$ (based on the total amount of the filler) of the coupling agent NZ12.

The inert alumina was used as a model to optimise the extrusion compounding setup adequate for the efficient producing of CAS and SI composites. After the adjustment of the referred parameters, the SI polymeric matrix was reinforced with the bioactive TCP.

The extruded compounds (in the form of pellets) were molded into ASTM tensile test bars $\left(2 \times 4 \mathrm{~mm}^{2}\right.$ of cross section), after being conditioned $\left(60^{\circ} \mathrm{C}\right.$ over $\left.24 \mathrm{~h}\right)$ until the respective moisture content reached $10-12 \%$. These specimens were molded using a DEMAG D25 NC 4 under optimized processing conditions. Subsequently, the injectionmolded samples were conditioned at $23^{\circ} \mathrm{C}$ and $60 \%$ relative humidity $(\mathrm{RH})$ for at least 1 week.

\section{Mechanical and morphological characterization}

To assess the mechanical performance of the new SI and CAS thermoplastics, tensile tests were performed on a Zwick Z010 universal mechanical testing machine, in a controlled environment $\left(20^{\circ} \mathrm{C}\right.$ and $55 \%$ relative humidity). The secant modulus at $1 \%$ strain $\left(\mathrm{E}_{1 \%}\right)$, the ultimate tensile strength (UTS), and the strain at break $\left(\sigma_{\mathrm{r}}\right)$ were evaluated.

Tensile fracture surfaces were observed by scanning electron microscopy (SEM) in a Leica Cambridge S360 microscope for morphological characterization of the fracture surfaces, filler distribution, and interfacial interactions between the filler and the polymeric matrix.

\section{In vitro degradation tests}

Molded specimens of SI and CAS materials and composites were weighed and aged up to 60 days in a isotonic 


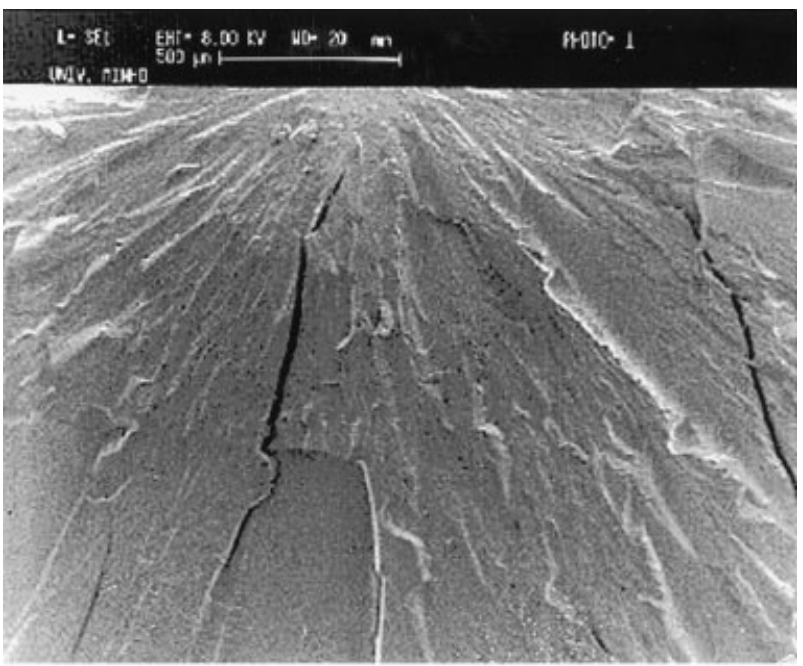

(a)

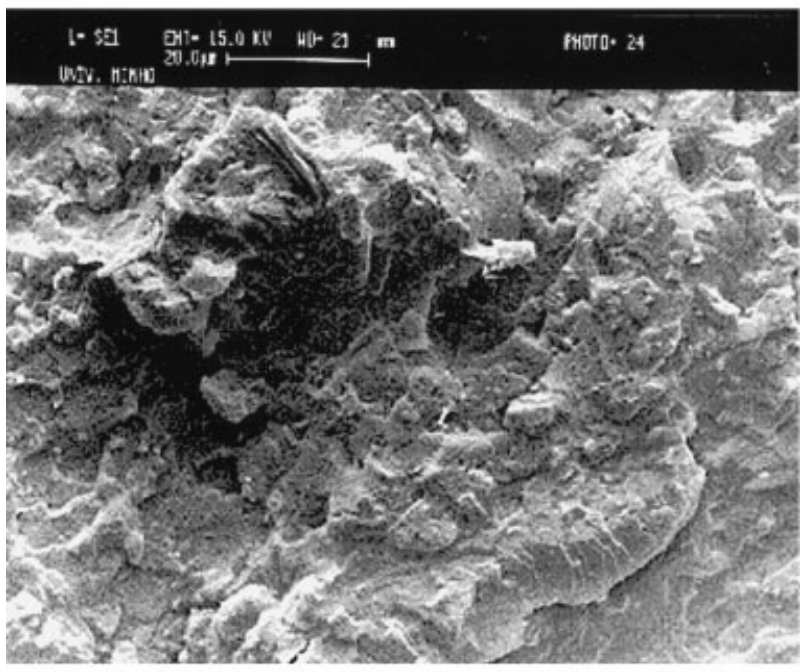

(b)

Figure 1. SEM micrographs of the fracture surfaces of (a) CAS $(\times 50)$ and $(b)$ CAS $+30 \mathrm{Al}_{2} \mathrm{O}_{3}(\times 1000)$.

saline solution (ISS; $\mathrm{NaCl} 0.154 M, \mathrm{pH}=7.4 \pm 0.02$ ) at $37^{\circ} \mathrm{C}$. A volume of $50.0 \pm 0.5 \mathrm{~mL}$ of ISS was used for three specimens (one batch) of approximately $1.300 \pm 0.005 \mathrm{~g}$ each. After being removed from the degradation solution, all the bars were immediately weighed to evaluate the respective water uptake as described in Equation (1):

$$
\text { Water uptake }(\%)=100 \times\left[\left(W_{w}-W_{i}\right) / W_{i}\right]
$$

where, $W_{i}$ and $W_{w}$ are the initial and wet weight of each sample, respectively. Subsequently, the samples were dried up to exhaustion in a vacuum oven at $40 \pm$ $2^{\circ} \mathrm{C}$ for 1 day to determine the respective weight loss as described in Equation (2):

$$
\text { Weight loss }(\%)=100 \times\left[\left(W_{i}-W_{d}\right) / W_{i}\right]
$$

where $W_{i}$ and $W_{d}$ are the initial and dry weight of each sample, respectively.

The degradation solutions were analyzed by atomic

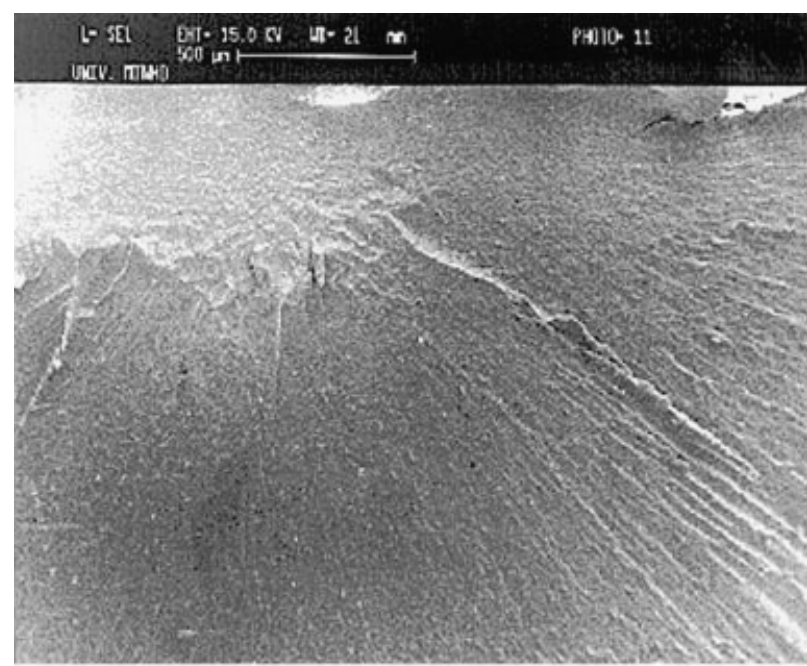

(a)

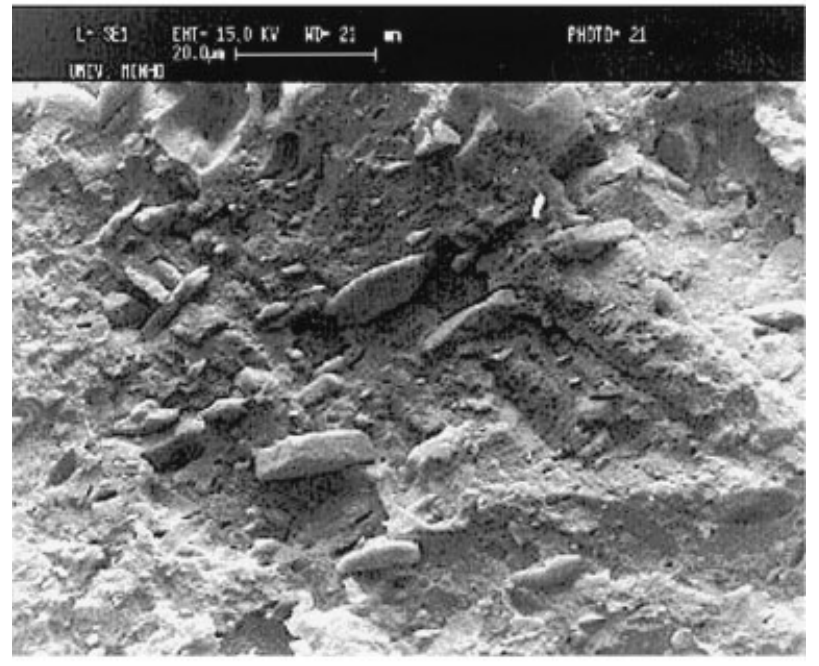

(b)

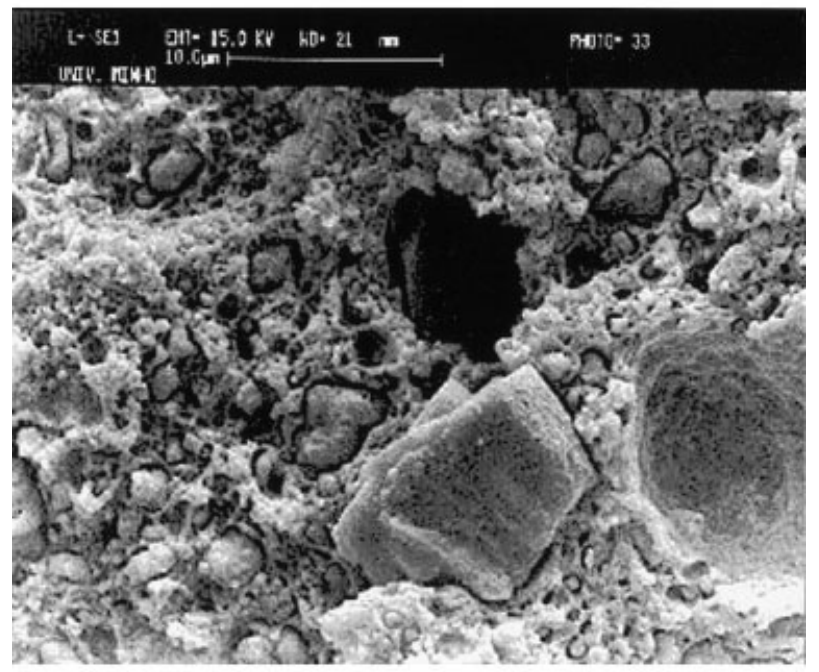

(c)

Figure 2. SEM micrographs of the fracture surfaces of (a) SI $(\times 50)$; (b) SI $+30 \mathrm{Al}_{2} \mathrm{O}_{3}$; and (c) SI + 30TCP $(\times 1000)$. 


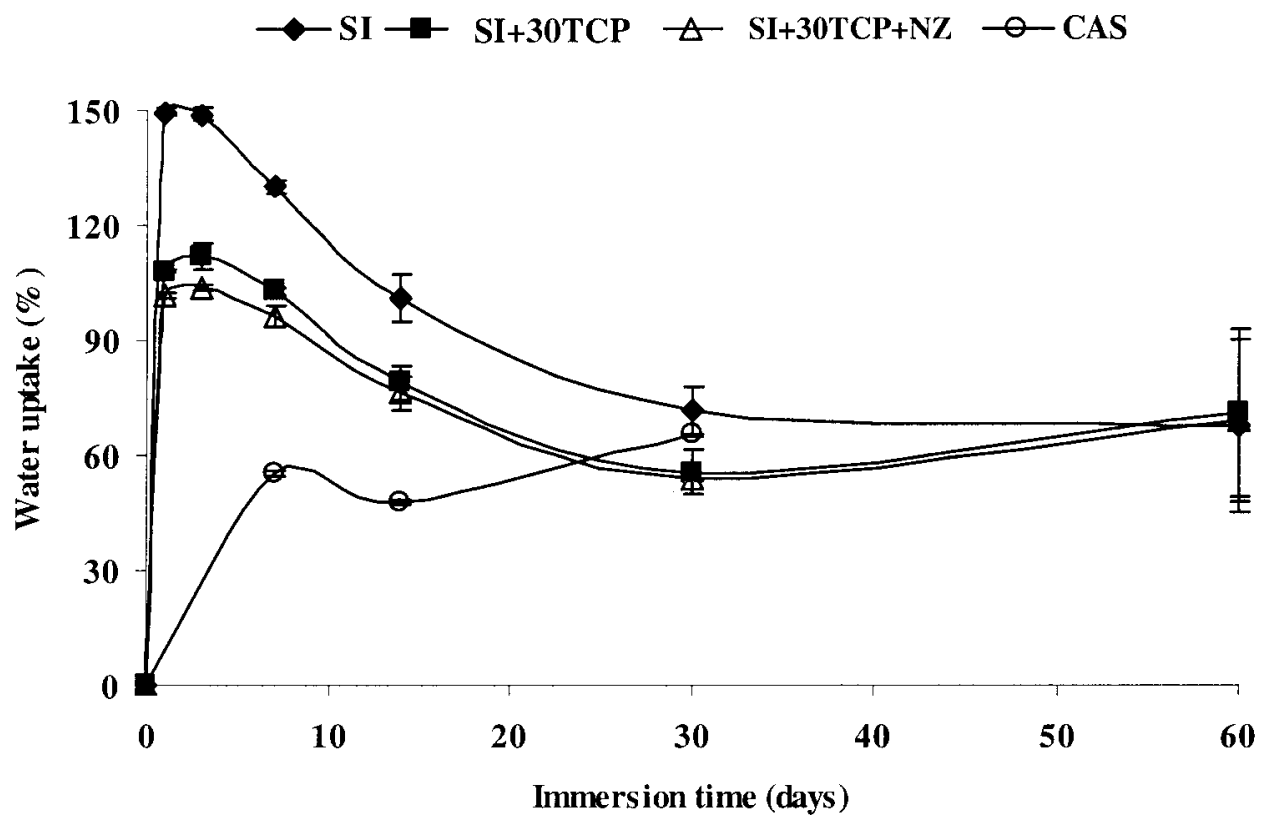

Figure 3. Water uptake of CAS and SI materials and respective composites, as a function of immersion time, in ISS.

emission spectrometry (inductive coupled plasma) to quantify the calcium and phosphorous release kinetics as a function of the immersion time $\left([\mathrm{Ca}]_{\mathrm{deg}}\right.$ and $\left.[\mathrm{P}]_{\operatorname{deg}}\right)$.

\section{Bioactivity tests}

Molded bars of SI and CAS materials and composites were immersed for several prefixed aging periods $(0,5,7$, 14 , and 30 days) in a simulated body fluid (SBF) solution (prepared as described by $\mathrm{Kim}^{21}$ ) at $37^{\circ} \mathrm{C}$ and $\mathrm{pH}=7.4 \pm$ 0.02 . After being removed from the solutions, the samples were dried for 1 day in an oven at $40 \pm 2^{\circ} \mathrm{C}$. The specimen surfaces, subjected to different immersion times, were morphologically examined by SEM and compared with the surface of the correspondent material without immersion (native material). The degree of extension of the apatite layer formed on the materials surface is an indication of their level of bioactivity. The dried materials were further analyzed by thin-film X-ray diffraction (TF-XRD). The referred analysis was performed in a diffractometer Philips $X^{\prime}$ Pert MPD at $1 \mathrm{~s}$ of path time and with a divergent beam at 1 degree. The SBF

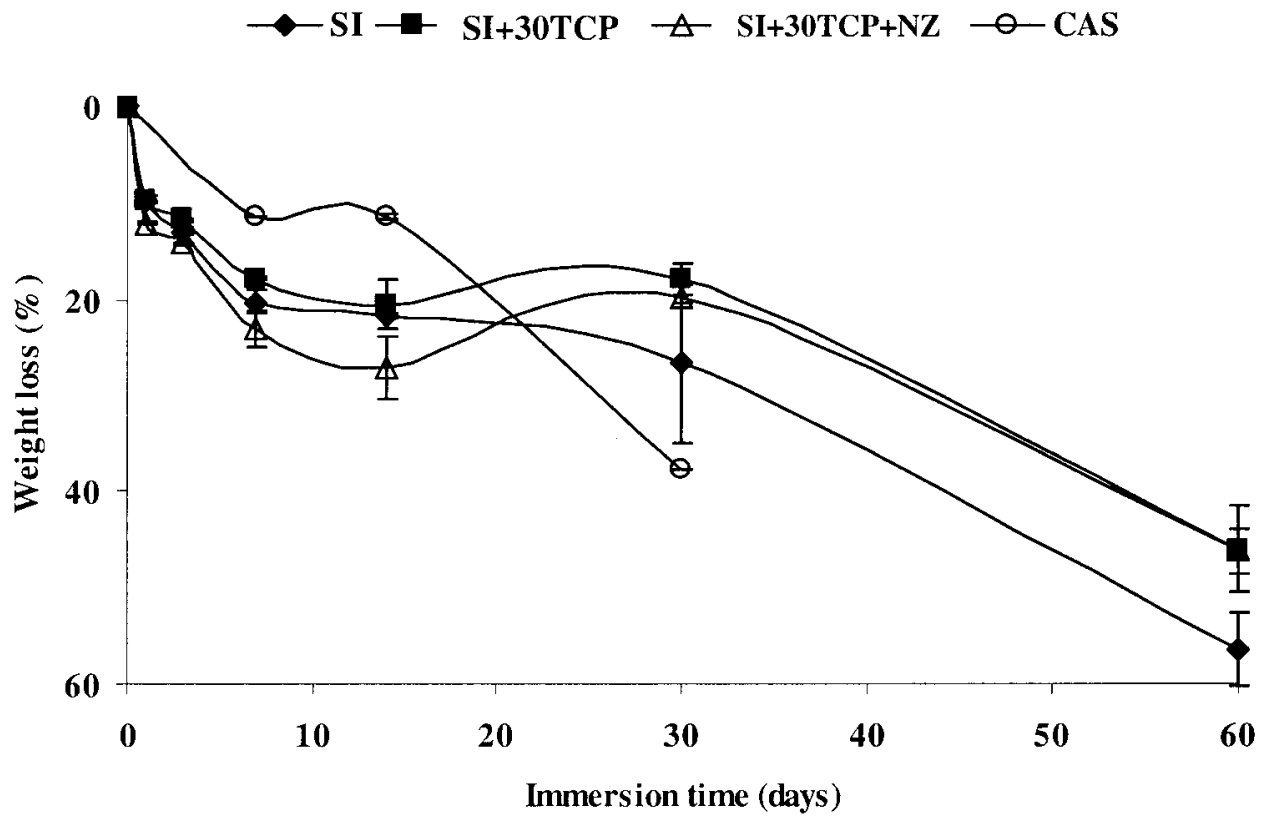

Figure 4. Weight loss of CAS and SI materials and respective composites, as a function of immersion time, in ISS. 


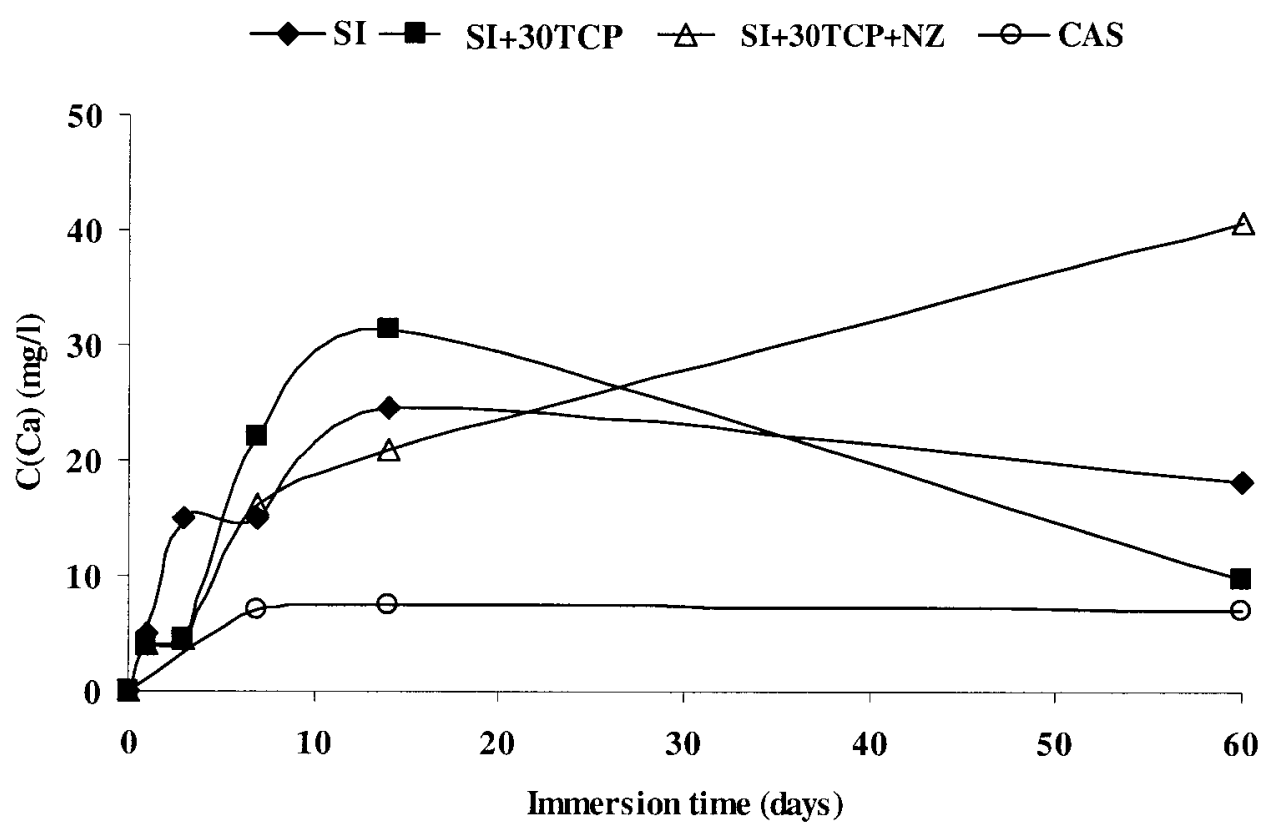

Figure 5. Calcium release kinetics $\left([\mathrm{Ca}]_{\mathrm{deg}}\right)$ of CAS and SI materials and respective composites, as a function of immersion time, in ISS.

solutions, after removal of the samples, were also analyzed by inductive coupled plasma for the quantification of the calcium and phosphorous concentrations ([Ca $]_{\text {bioact }}$ and $\left.[\mathrm{P}]_{\text {bioact }}\right)$. To subtract the amounts of calcium and phosphorous present in the SBF solution as a result of the materials degradation $\left([\mathrm{Ca}]_{\mathrm{deg}}\right.$ and $\left.[\mathrm{P}]_{\mathrm{deg}}\right)$, the final calcium and phosphorous concentrations $\left([\mathrm{Ca}]_{\text {final }}\right.$ and $\left.[\mathrm{P}]_{\text {final }}\right)$ were corrected by the following:

$$
[\text { Ca or } \mathrm{P}]_{\text {final }}=[\text { Ca or P }]_{\text {bioact }}-[\text { Ca or P }]_{\text {deg }}
$$

\section{RESULTS AND DISCUSSION}

\section{Mechanical properties}

The effects of the alumina and TCP content and of the coupling agent on the mechanical properties of the CAS and SI thermoplastics are compared in Table I. CAS-based polymers and composites exhibit higher

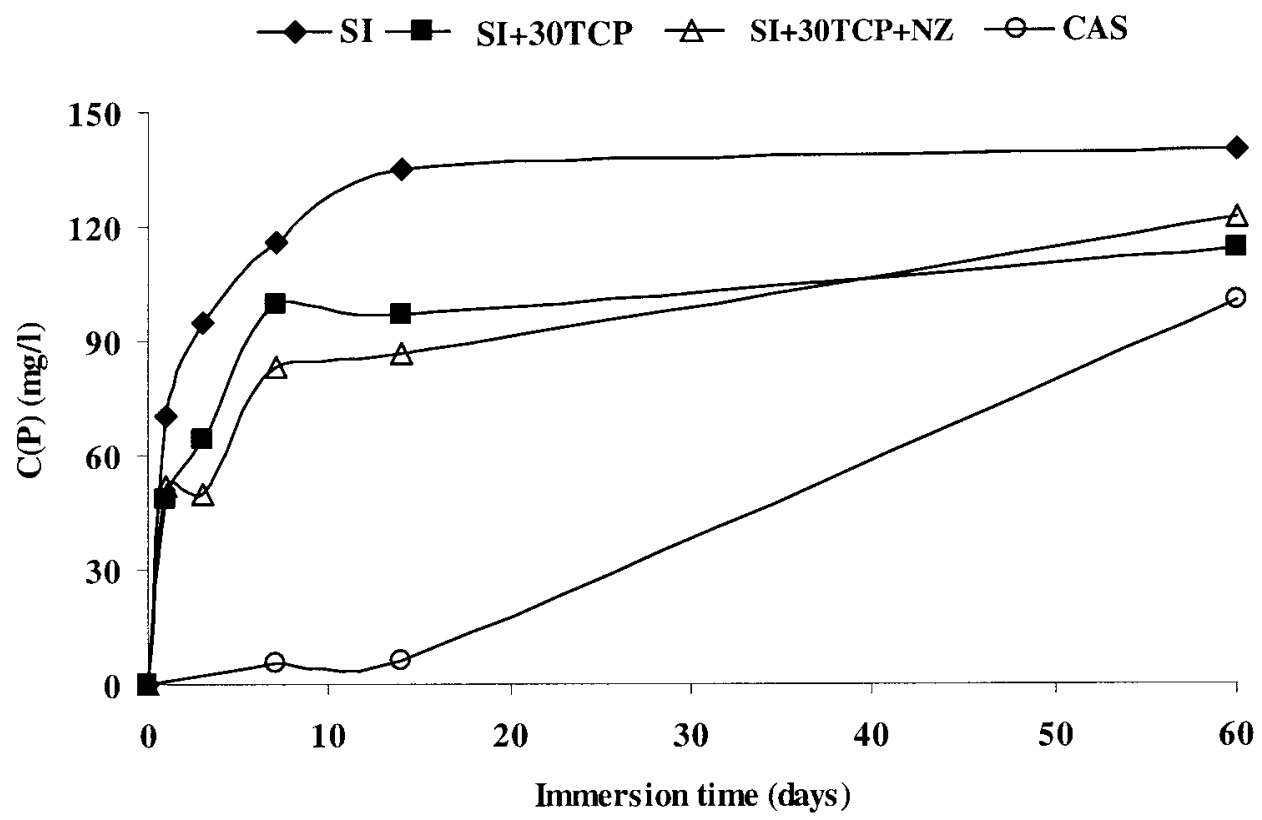

Figure 6. Phosphorous release kinetics $\left([\mathrm{P}]_{\mathrm{deg}}\right.$ ) of CAS and SI materials and respective composites, as a function of immersion time, in ISS. 


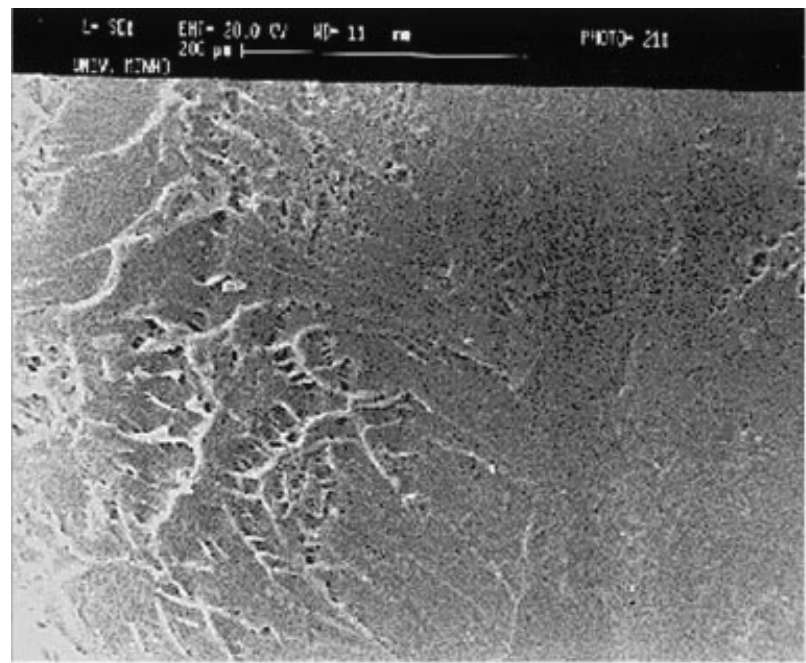

(a1)

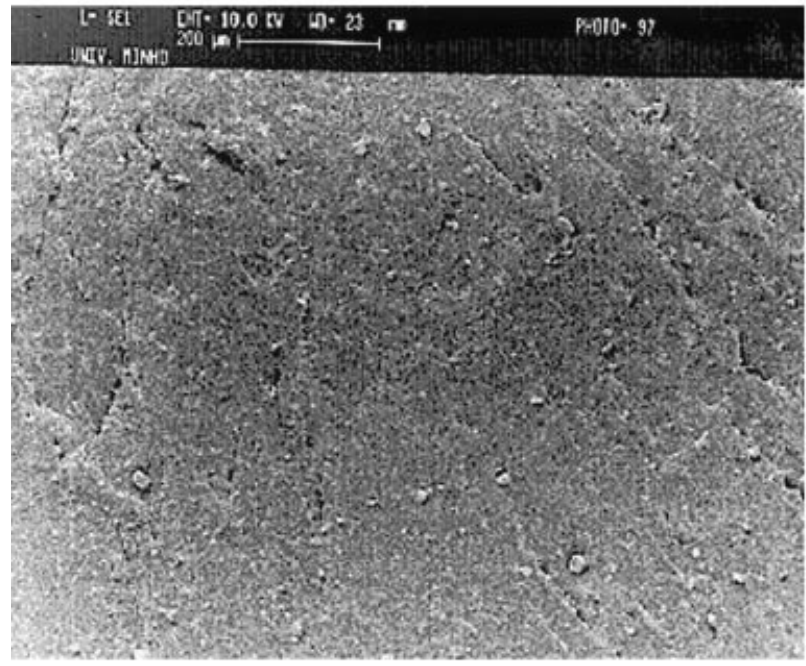

(c1)

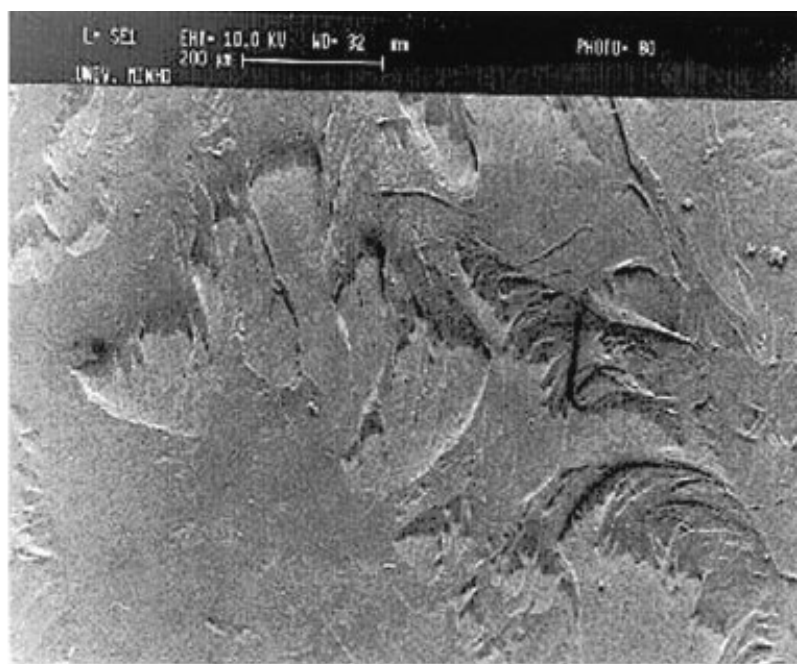

(b1)

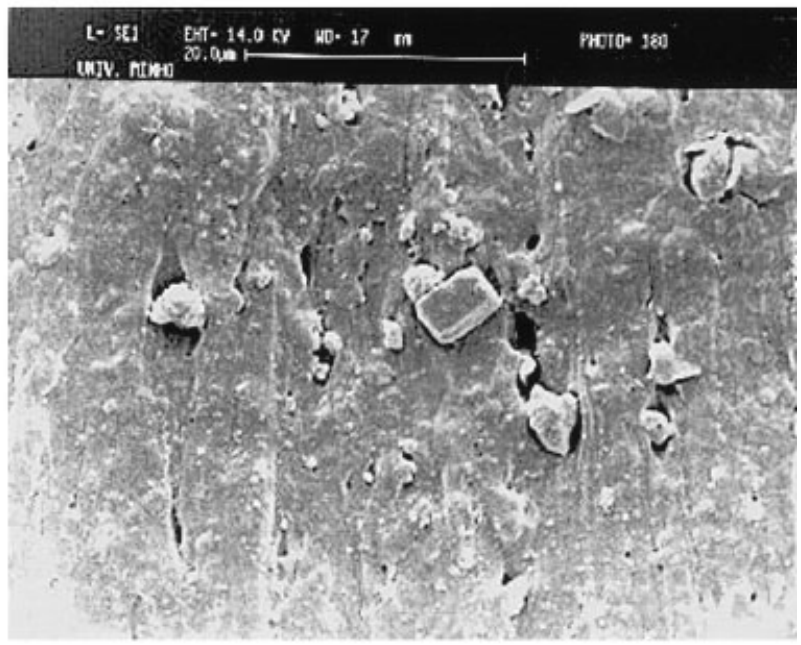

(d1)

Figure 7. SEM micrographs of the protein materials and composites surfaces after immersion in a SBF solution for 1) 0 and 2) 14 days ( $\times 2000)$ : (a) CAS, (b) SI, (c) SI + 30TCP, and (d) SI + 30TCP + NZ12.

stiffness than the SI materials. For $3.90 \%$ of moisture content, the E-modulus of CAS mouldings is 2534 $\mathrm{MPa}$, being increased by the alumina content. In fact, CAS $+30 \mathrm{Al}_{2} \mathrm{O}_{3}$ is a rigid and brittle thermoplastic with $3479 \mathrm{MPa}$ of stiffness and $3.22 \%$ strain at break (with $3.22 \%$ of moisture content). SEM micrographs [Fig.1(a)] show the brittle character of CAS, which exhibited a smooth surface center region where the crack initiated and grew slowly. The CAS composites fracture surfaces revealed a good distribution of the alumina particles and a good polymer/ceramic interfacial interaction [Fig, 1(b)].

SI materials also present a brittle behavior, but with fairer mechanical properties, namely $1256 \mathrm{MPa}$ of Emodulus and $16.5 \%$ strain at break $(5.06 \%$ of moisture content). The introduction of alumina proved to be even more effective in reinforcing SI $(97 \%$ gain for SI +
$30 \mathrm{Al}_{2} \mathrm{O}_{3}$ ). The SEM micrograph in Figure 2(a) illustrates a typical smooth and brittle fracture of SI. The alumina composites reveal a good filler distribution and good polymer/ceramic interfacial interaction [Fig. 2(b)].

When reinforced with TCP, the E-modulus was found to decrease sharply ( $29 \%$ loss for SI + 30TCP; Table I). The observed reduction in properties of these SI composites is consistent with the fracture surface observations [Fig. 2(c)], which present a poor distribution of the filler, a poor polymer/ceramic interaction and a tendency for filler/filler contact, which also is known to reduce the mechanical properties. The introduction of the amino-based coupling agent NZ12 also caused the plasticization of the SI matrix, especially when reinforced with alumina. NZ12 showed some affinity in relation to the TCP composite avoiding an even higher loss in stiffness. 


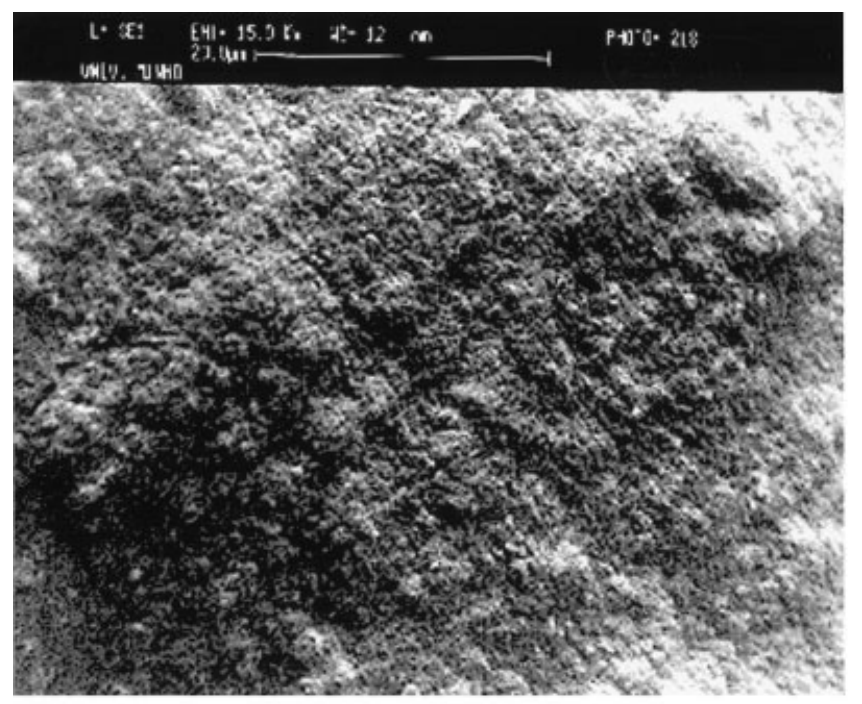

(a2)

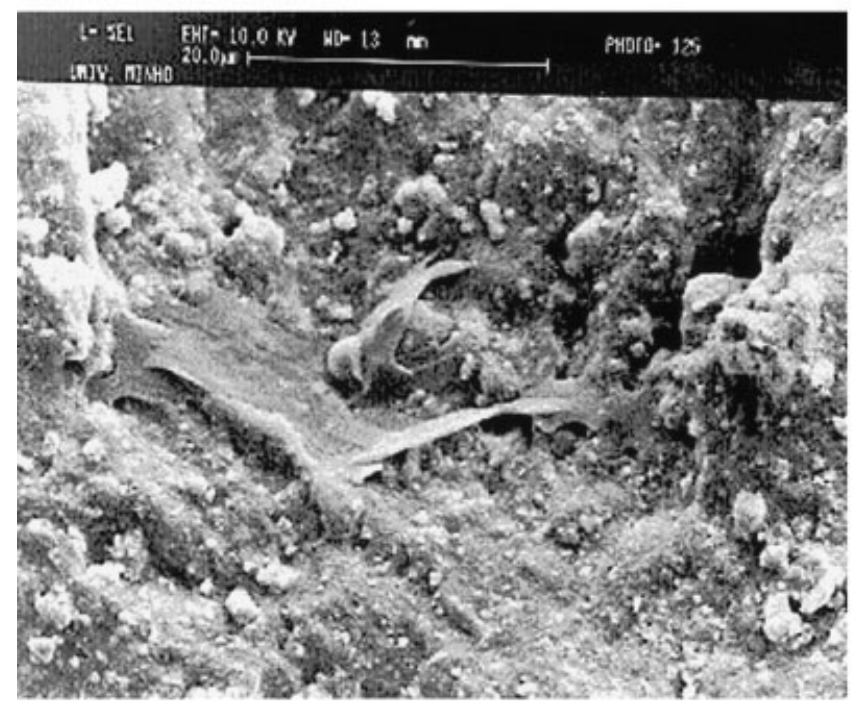

(c2)

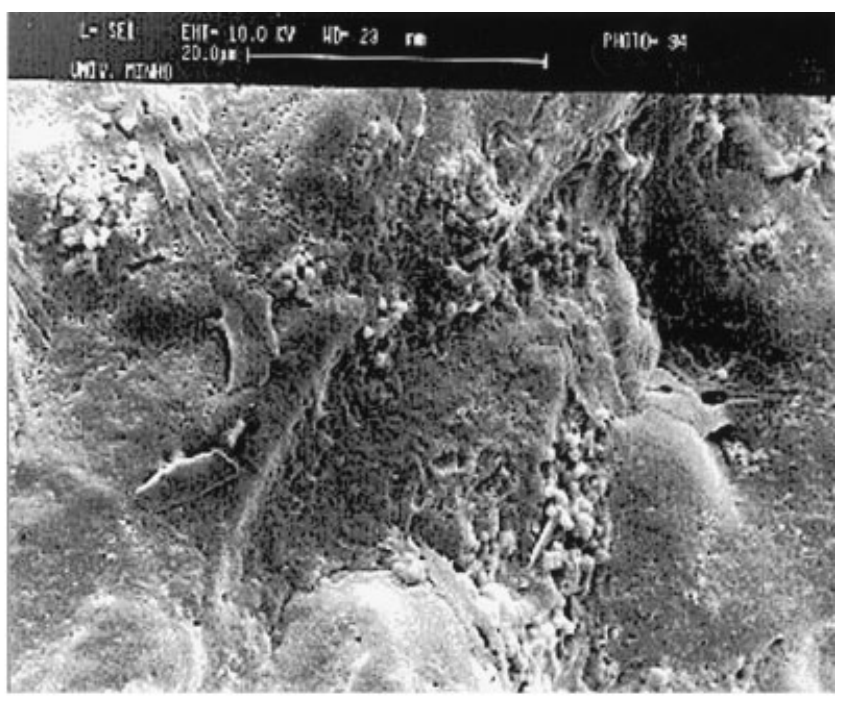

(b2)

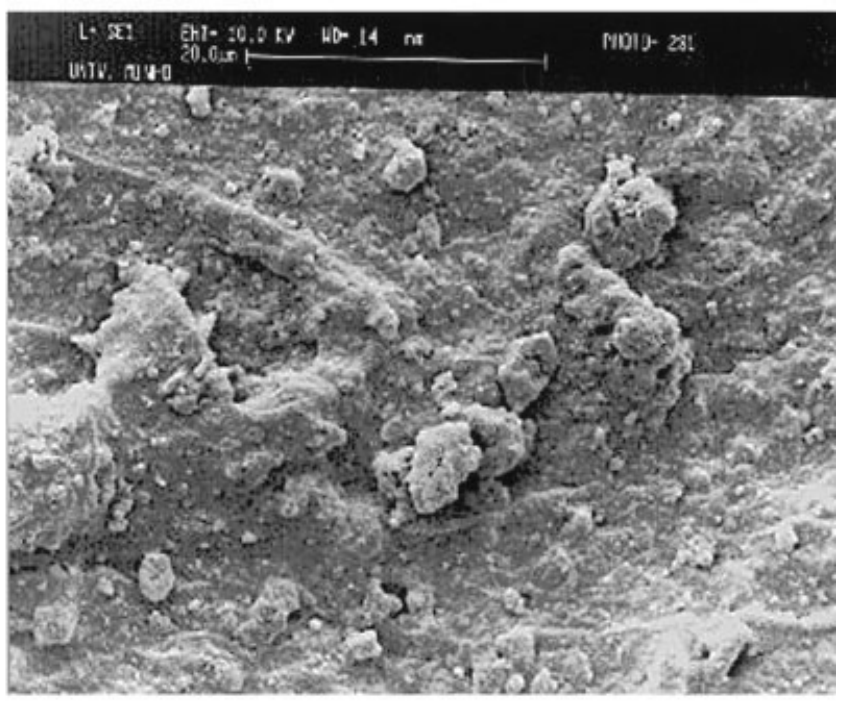

(d2)

Figure 7. (Continued from the previous page)

\section{In vitro degradation tests}

Three degradation stages were noticeable in the in vitro degradation behavior of SI material and composites. The first one, between 0 and 6 immersion days, was essentially related with the leaching of plasticisers (glycerol) and low molecular weight $\left(M_{\mathrm{w}}\right)$ polymeric chains (resulted from thermo-oxidative degradation occurred during extrusion). A high water uptake (Fig. 3 ) and a fast degradation occurred during the first week of immersion (weight loss of $20 \%$; Fig. 4 ). When compatibilized with the coupling agent NZ 12, SI presented an even higher weight loss (45\%) because of the plasticizing and destructurizing effect of this agent over the polymeric matrix.

The second degradation stage, typically between 15 and 30 immersion days, was essentially characterized by a decrease in the degradation rate. The stabilization of the weight loss (around 20\%; Fig. 4) and decrease in water uptake to around $75 \%$ (Fig. 3) were the main relevant aspects.

During the first and the second degradation stages, the SI material and composites released all the calcium $\left([\mathrm{Ca}]_{\mathrm{deg}}=25 \mathrm{mg} / \mathrm{L}\right)$ and phosphorous $\left([\mathrm{P}]_{\mathrm{deg}}=140\right.$ $\mathrm{mg} / \mathrm{L}$ ) to the degradation solutions (Fig. 5 and 6). The only exception was SI + 30TCP + NZ12, which presented a slower release of calcium as a function of immersion time. During the first 2 weeks of immersion, this composite only released half of its total calcium concentration. This fact confirms the existence of a certain affinity of the coupling agent in relation to the TCP ceramic.

The third degradation stage, between 30 and $60 \mathrm{im}$ - 


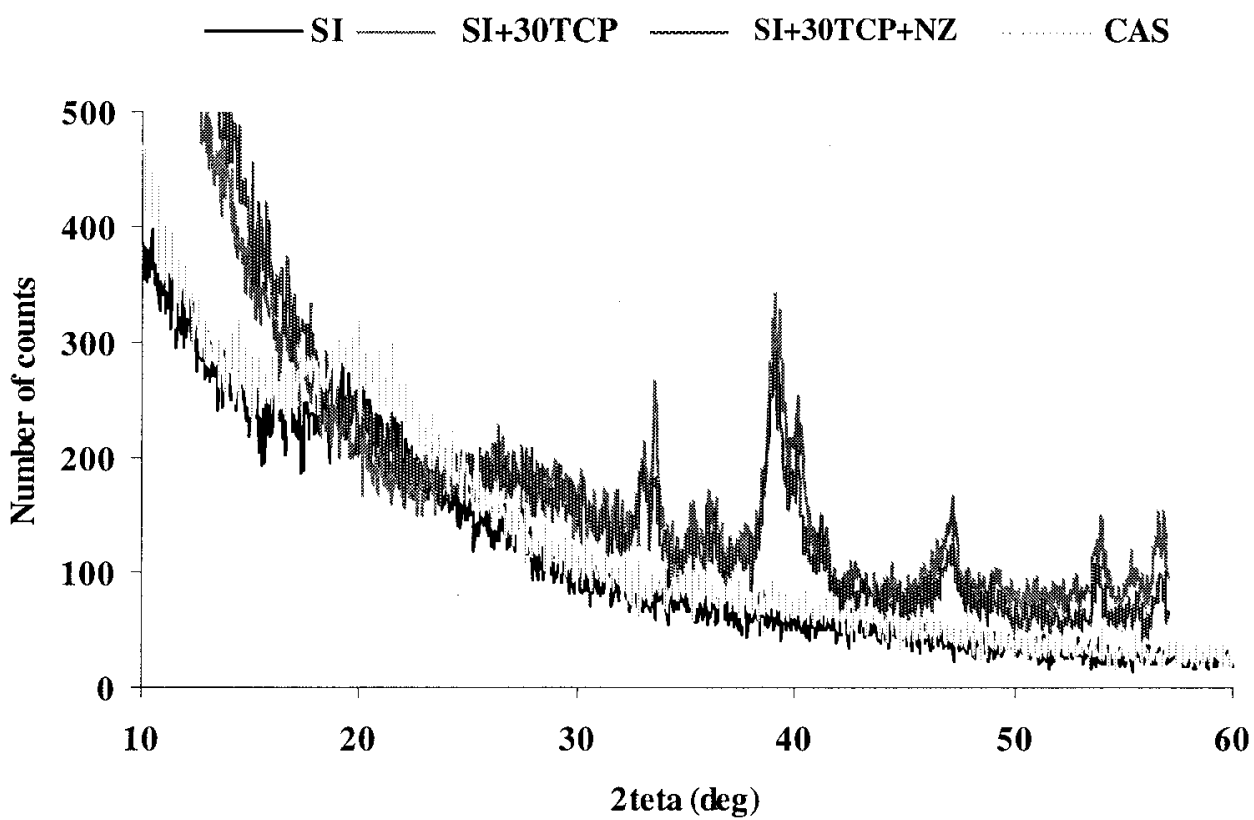

(a)

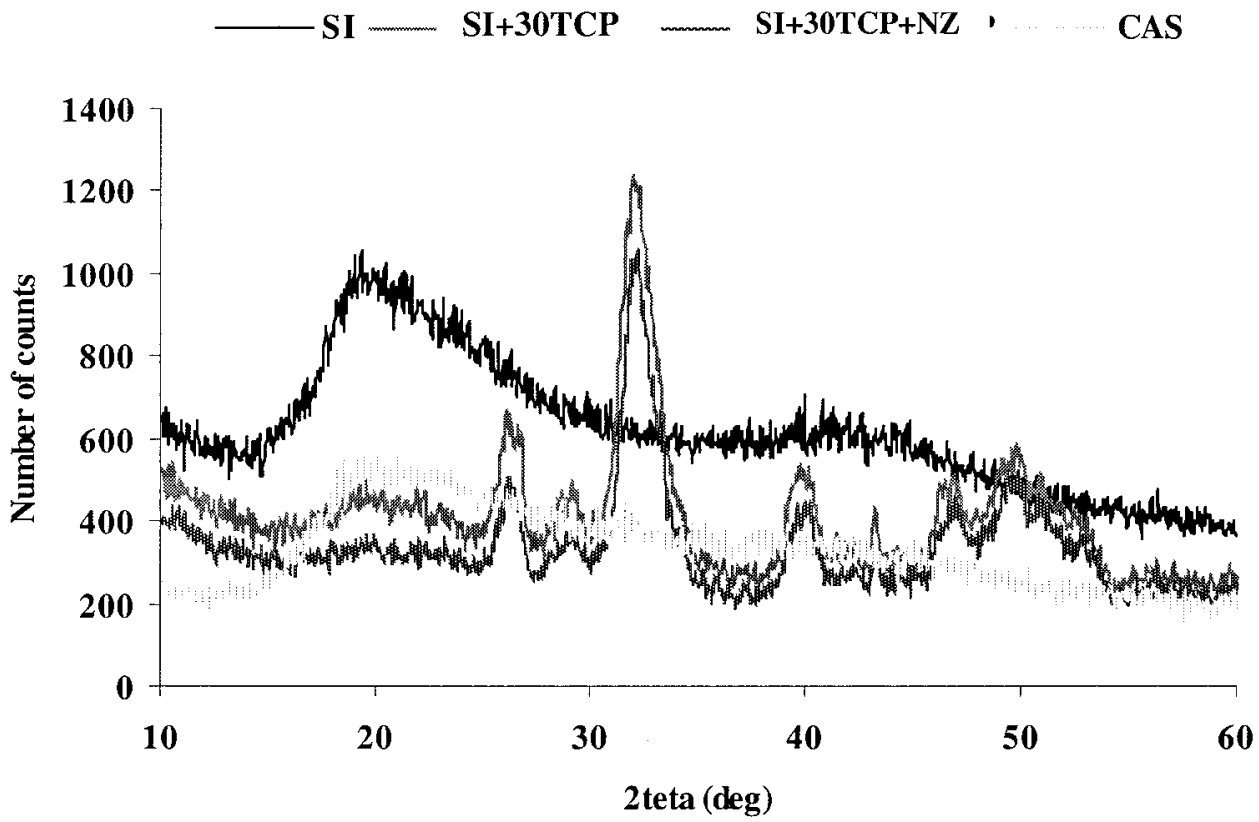

(b)

Figure 8. TF-XRD pattern of the protein materials and composites surfaces after immersion in a SBF solution for (a) 0 and (b) 30 days.

mersion days, was characterized by the apparent beginning of a chemical degradation (hydrolysis and chain breakage). The weight loss doubled (approximately $50 \%$; Fig. 4) and the water uptake (Fig. 3) remained constant. This final stage should correspond to the fragmentation of the proteins internal structure and, consequently, dissolution of the resulting fragments.

The CAS-based compounds also showed three different stages in the in vitro degradation tests. The leaching of plasticizers $(30 \%$ glycerol for CAS) was the main factor responsible for the weight loss of CAS during the first stage (Fig. 4), between 0 and 6 immersion days.

The second degradation stage, typically during the second week of immersion, was characterized mainly by a decrease in the degradation rate. The stabilization of the weight loss and water uptake (Figs. 3 and 4), as well as the complete release of calcium to the degradation solutions (Fig. 5) were the most important phenomena occurring during this stage.

During the third degradation stage, after 2 weeks of 


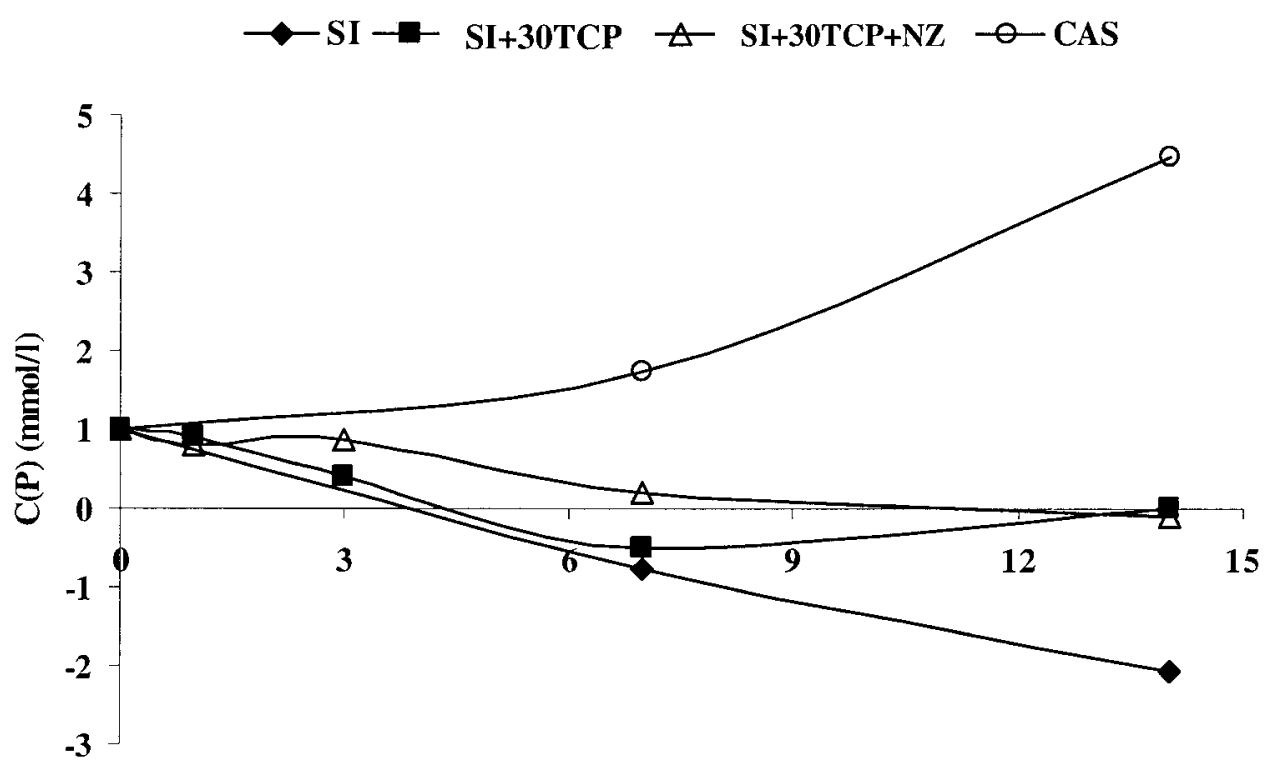

Immersion time (days)

Figure 9. Phosphorous release kinetics $\left([\mathrm{P}]_{\text {final }}\right)$ for the protein materials and composites, as a function of immersion time, in a SBF solution.

immersion, the CAS degradation rate increased. The weight loss was four times higher (approximately $45 \%$; Fig. 4), the water uptake remained constant (Fig. 3), and the CAS released its total phosphorous amount (Fig. 6). This stage should correspond to a beginning of the chemical degradation, with respective breakage of the CAS internal structure, which was probably initiated by the decrease in $\mathrm{pH}$ of the degradation solutions.

\section{Bioactivity tests}

After 30 days of immersion in a SBF solution, CAS showed no evidence of nucleation of a bioactive film (Ca-P) on its surface, as observed by SEM (Fig. 7) and confirmed by TF-XRD (Fig. 8).

This result indicates a nonbioactive behavior of CAS, which may result from the impossibility of precipitation of a Ca-P film in the surface of the CAS samples resulting from the continuous increase of $[\mathrm{P}]_{\text {final }}$ and decrease of $[\mathrm{Ca}]_{\text {final }}$ in the SBF solution, as a function of time (Figs. 9 and 10).

When immersed in a SBF solution, after 1 week of immersion, SI evidenced by SEM (Fig. 7) the formation of only some Ca-P nuclei on its surface. However, even after 1 month of immersion in SBF, no distinct Ca-P layers could be observed. The TF-XRD results (Fig. 8) were in agreement with the SEM observations and peaks correspondent to crystalline Ca-P phases (mainly hydroxylapatite or TCP) could be hardly detected in the surface of the protein.

As evidenced by SEM (Fig. 7), SI + 30TCP showed nucleation and growth of a bioactive Ca-P film on its surface, characteristics of a highly bioactive material. The TF-XRD results (Fig. 8) reinforced the SEM observations, which showed an increment of the crystalline phases (peak intensity) on the composite surface after 14 days of immersion. The XRD pattern resulting from the Ca-P film is similar to that of the bone apatite. The decreased of $[\mathrm{Ca}]_{\text {final }}$ and $[\mathrm{P}]_{\text {final }}$ in the SBF solution, as a function of time, resulted in the Ca-P film precipitation, confirming the bioactivity of the referred material (Figs. 9 and 10).

When treated with NZ12, the nucleation and growth of the Ca-P film was faster, as confirmed by SEM (Fig. 7) and TF-XRD (Fig. 8). This fact can be explained by the influence of the coupling agent on the decrease of the kinetics of calcium and phosphorous release to the degradation solutions (Figs. 5 and 6). As a result, a decrease of $[\mathrm{Ca}]_{\text {final }}$ and $[\mathrm{P}]_{\text {final }}$ in the SBF solution was observed (Figs. 9 and 10), as a function of time, leading to an in vitro bioactive behavior. Consequently, it is expected that these materials will be able to directly bond to bone, without fibrous encapsulation, when implanted. Nevertheless, further testing, mainly in terms of their immunogenicity, obviously need to be performed.

Concerning this point, it is known that soybean proteins have immunological activity and can act as allergens in humans. ${ }^{22,23}$ However, as pointed out in the literature, ${ }^{24}$ there is no evidence that soy proteins possess any special allergenic property when compared with other proteins. As the use of animal origin proteins, such as collagen and gelatin, in biomedical applications is a common practice, ${ }^{12-14}$ it is also expected the possibility of introduce alterna- 


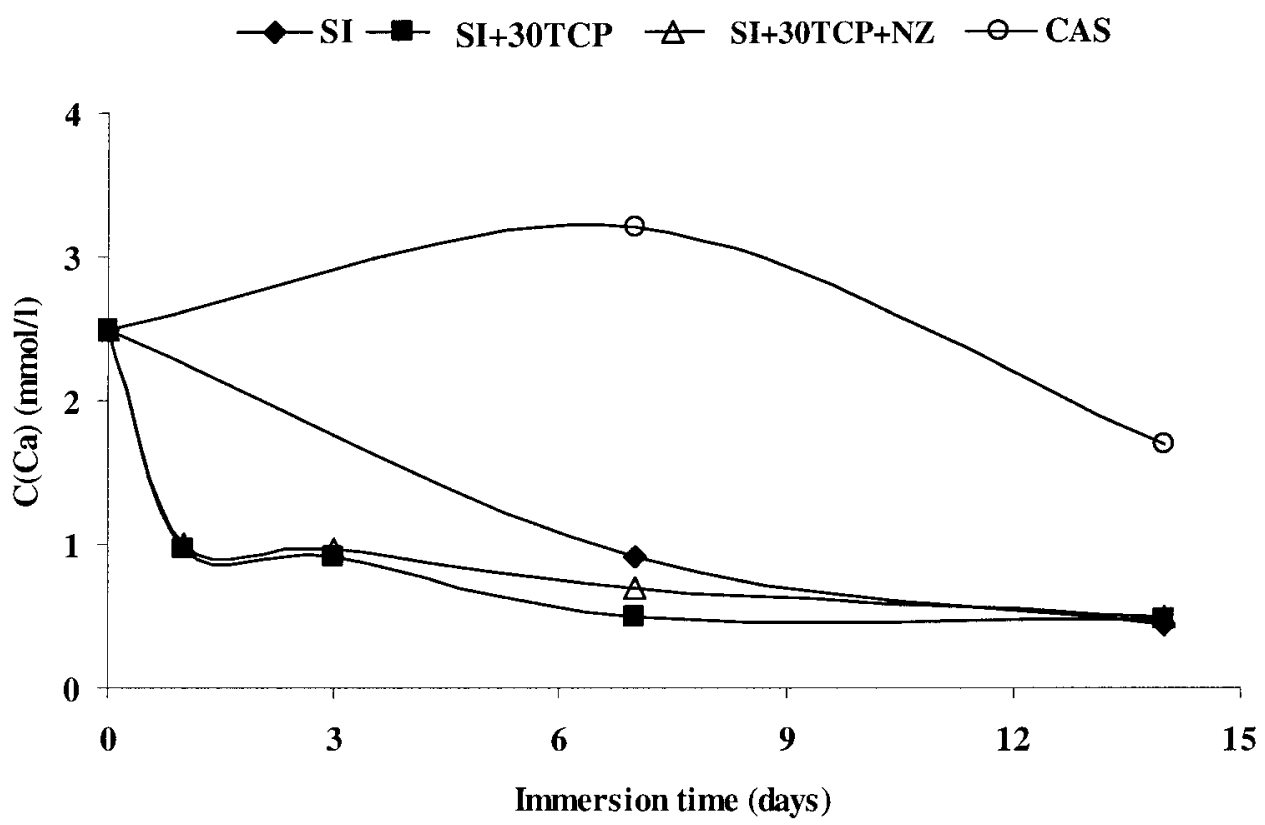

Figure 10. Calcium release kinetics $\left([\mathrm{Ca}]_{\text {final }}\right)$ for the protein materials and composites, as a function of immersion time, in a SBF solution.

tive protein materials, specially from plant origin, like soy.

\section{CONCLUSIONS}

This preliminary study confirms that the developed casein and soybean protein-based thermoplastics present a suitable range of mechanical and degradation properties, as well as a bioactive character (especially when reinforced with bone-like ceramics) which might eventually allow for their use as biomaterials.

For many applications, it will be necessary to create further improvements in their mechanical strength and to enhance their hydrolytic stability. However, as a result of the high versatility of this type of materials, a broad range of physical and chemical modifications can be performed to tailor their properties towards the diverse requirements of different biomedical applications.

\section{References}

1. Reis RL, Cunha AM. Characterization of two biodegradable polymers of potential application within the biomaterials field. J Mat Sci 1995;6:786-790.

2. Reis RL, Mendes SC, Cunha AM, Bevis M J. Processing and in vitro degradation of starch/EVOH thermoplastic blends. Polym Int 1997;43:347-352.

3. Reis RL, Cunha AM, Allan PS, Bevis MJ. Structure development and control of injection-moulded hydroxyapatite-rein- forced starch/EVOH composites. Adv Polym Tech 1997;16: 263-277.

4. Danniels AU, Adriano KP, Smuts WP, Chang MKO, Keller J. Evaluation of absorbable poly(ortho esters) for use in surgical implants. J Appl Biomater 1994;5:51-64.

5. Adriano KP, Pohjonen T, Tomalla P. Processing and characterisation of absorbable polylactide polymers for use in surgical implants. J Appl Biomater 1994;5:133-140.

6. Koller I, Owen AJ. Starch filled PHB and PHB/HV copolymer. J Polym Int 1996;39:175-181.

7. Chen G, Ushida T, Tateishi T. Hybrid materials for tissue engineering: a preparative method for PLA or PLGA-collagen hybrid sponges. Adv Mater 2000;12:455-457.

8. Gennadios A, Brandenburg AH, Weller CL, Testin RF. Effect of $\mathrm{pH}$ on properties of wheat gluten and soy protein isolate films. J Agric Food Chem 1993;41:1835-1839.

9. Ewart JAD. Action of glutaraldehyde, nitrous acid or chlorine on wheat proteins. J Sci Food Agric 1968;19:370-373.

10. Feeney RE, Blankenhorn G, Dixon HBF. Carbonyl-amine reactions in protein chemistry. Adv Protein Chem 1975;29: 135-203.

11. Cheftel JC, Cuq J-L, Lorient D. Amino-acids, peptides and proteins. In: Fennema OR, editor. Food chemistry. New York: Marcel Dekker Inc.; 1985. p 245-369.

12. Kuijpers A, Engbers GHM, Krijgsveld J, Zaat SAJ, Dankert J, Feijen J. Cross-linking and characterisation of gelatin matrices for biomedical applications. J Biomater Sci Polym Edn 2000;11: 225-243.

13. Rault I, Frei V, Herbage D, Abdul-Malak N, Huc A. Evaluation of different chemical methods for cross-linking collagen gel, films and sponges. J Mater Sci 1996;7:215-221.

14. Du C, Cui FZ, Zhang W, Feng QL, Zhu XD, de Groot K. Formation of calcium phosphate/collagen composites through mineralization of collagen matrix. J Biomed Mater Res 2000;50: 518-527.

15. Kunte LA, Gennadios A, Cuppett SL, Hanna MA, Weller CL. Cast films from soy protein isolates and fractions. Cereal Chem 1997;74:115-118. 
16. Schilling $\mathrm{CH}$, Babcock $\mathrm{T}$, Wang S, Jane J. Mechanical properties of biodegradable soy-protein plastics. J Mat Res 1995;10:2197-2202.

17. Gontard N, Guilbert S, Cuq J-L. Edible wheat gluten films: influence of the main process variables on film properties using response surface methodology. J Food Sci 1992;57:190-199.

18. Banker GS. Film coating, theory and practice. J Pharm Sci 1966;55:81-90.

19. Brandenburg AH, Weller CL, Testin RF. Edible films and coatings from soy protein. J Food Sci 1993;58:1086-1089.

20. Huang HC, Hammond EG, Reitmeier CA, Myers DJ. Properties of fibers produced from soy protein isolate by extrusion and wet-spinning. JAOCS 1995;72:1453-1460.
21. Kim KM, Kishimoto K, Miyaji F, Kokubo T, Yao T, Suetsugu Y, Tanaka J, Nakamura T. Composition and structure of the apatite formed on PET substracts in SBF modified with various ionic activity products. J Biomed Mater Res 1999;46:228-235.

22. Ogawa A, Samoto M, Takahashi K. Soybean allergens and hypoallergenic soybean products. J Nutr Sci Vitaminol 2001; 46:271-279.

23. Arita K, Babiker E-E, Azakami H, Kato A. Effect of chemical and genetic attachment of polysaccharides to proteins on the production of IgG and IgE. J Agric Food Chem 2001;49:2030-2036.

24. Kilshaw PJ, Sissons JW. Allergenicity of soy proteins. Res Vet Sci 1979;27:361-367. 